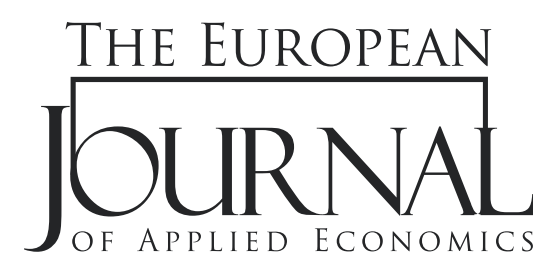

EJAE 2020, 17(2): 1 - 18

ISSN 2406-2588

UDK: 005.961:005.914.3]:364-3(497.11)

DOI: 10.5937/EJAE17-27375

Original paper/Originalni naučni rad

\title{
AN ANALYSIS OF FACTORS INFLUENCING THE DEVELOPMENT OF SOCIAL ENTERPRISES IN THE REPUBLIC OF SERBIA
}

\author{
Faculty of Economics, \\ University of Niš, \\ Serbia
}

Maja Ivanović Djukić*, Marija Petrović Randjelović, Miljana Talić

\begin{abstract}
:
The paper investigates the impact of different factors on the establishment and development of social enterprises (SPs). The aim of this paper is to identify the key stimulants and restrictions of development of SPs in the Republic of Serbia, and to propose measures, the application of which can increase their long-term sustainability. The paper is based on exploratory research using data covering 27 interviews with founders of social enterprises in the Republic of Serbia. By applying the methods of regression analysis, it was found that favorable financial resources (especially grants) are the key stimulants for the establishment of social enterprises, while the enthusiasm of managers of social enterprises has the greatest impact on their development. It was found also that legal regulations and the macroeconomic environment, as well as difficulties in accessing the market, are serious restrictions on the establishment of social enterprises, while lack of knowledge in the field of marketing and management limit the development of social enterprises in the Republic of Serbia.
\end{abstract}

\section{Article info:}

Received: July 4, 2020

Correction: September 4, 2020

Accepted: September 10, 2020

\section{Keywords:}

Social enterprises,

stimulants, restrictions, long-term sustainability.

\section{INTRODUCTION}

Modern society is characterized by the presence of numerous social problems, such as: unemployment, poverty, social exclusion, crime, economic inequality, etc. To solve these problems, policymakers in many countries around the world are trying to find innovative solutions. One of the ways to solve the problem of long-term unemployment and exclusion of certain social groups is the establishment and development of economically sustainable companies that have a social mission and for which the term social enterprises has been adopted (Bacq \& Janssen, 2011).

Social enterprise is any private activity conducted in the public interest, organized within an entrepreneurial strategy whose main goal is not to maximize profits, but to achieve certain economic and 
social goals, and can bring innovative solutions to the problem of social exclusion and unemployment (OECD/European Commission, 2013). EMES network researchers list the criteria that an organization needs to meet in order to be considered a social enterprise. On the one hand, four criteria are listed that reflect the economic and entrepreneurial dimensions of the organization: (1) continuous activity of production and sale of goods and/or services; (2) a high degree of autonomy; (3) a significant level of economic risk; and (4) a minimum amount of paid work. On the other hand, five criteria are listed that connect the social character of the entrepreneurial initiative: (1) an explicit goal for the benefit of the community; (2) an initiative launched by a group of citizens; (3) decision-making power that is not based on capital and ownership; (4) participatory nature including all actors of the activity; and (5) limited profit distribution (Defourni \& Nissens, 2006, p. 6).

Social enterprises play a very important role in society. They help to solve the problem of social inclusion and poverty reduction, provide support to vulnerable social groups (helping the elderly, taking care of children, etc.), participate in solving environmental problems, contribute to the preservation of old crafts, contribute to the development of science and culture, etc. (Hjorth, 2013). For that reason, most countries in the world encourage the development of this group of economic entities with a social mission (Rosandić, 2018). For example, the European Commission adopted new specific legislation in the field of social entrepreneurship, and EU Member States have created formal strategies or policies for supporting social enterprise development. In 2015, the Council adopted conclusions on promoting Social Economy. In 2020, the Commission developed a European Action Plan for Social Economy to enhance social innovation (Borzaga et al, 2020). Moreover, various forms of support for the development of social enterprises are provided at the national and local levels (networks and mutual support mechanisms; research, education and skills development, resources available to social enterprises etc.). Additionally, state bodies and nongovernmental organizations promote social entrepreneurship in order to raise the awareness of the population about the role and importance of these economic entities. Thanks to all these activities, the number of social enterprises and social entrepreneurs has been increasing worldwide (Borzaga, et al, 2020, p. 104).

However, a large number of social enterprises face a number of problems that have a disincentive effect on the intentions of social entrepreneurs, and which limit the development of already-established social enterprises. These problems can be very different, starting from difficulties in providing financial sources and the socialization of workers, to profit distribution, business expansion, understanding of the local community, etc. In order to stimulate the establishment of social enterprises and encourage their development, it is necessary to identify the factors that have the greatest impact (positive and negative) on their business. The subject of this paper is to identify the key success factors of social enterprises, focusing on the Republic of Serbia. The aim of the paper is to propose measures whose application can lead to the development of social entrepreneurship in the Republic of Serbia.

The paper will first analyze the success factors of social enterprises based on a review of the literature. Then, the situation in this field in the Republic of Serbia will be analyzed, and hypotheses will be formulated. The second part of the paper will examine the impact of various factors on the development of social enterprises using statistical methods on data collected by primary research in 27 social enterprises in the Republic of Serbia. In the conclusion, recommendations for social entrepreneurs and economic policy makers will be given. 


\section{LITERATURE REVIEW}

Entrepreneurs face a large number of problems, especially in the initial period after establishment. For that reason, many of them leave the business (Stefanovic, et al, 2013). Results from many empirical studies show that up to $20 \%$ of entrepreneurial ventures do not survive the first year of business (Fritsch et al., 2006). The situation is even more difficult regarding social enterprises. The number of factors which have an impact on the survival and success of the social enterprises is much higher compared to commercial enterprises, given that they aspire to create economic and social value (Moizer \& Tracey, 2010). In order to increase the survival rate of entrepreneurial ventures in the social sphere, it is very useful to identify factors that have a positive impact (stimulate the establishment and development of social enterprises), as well as constraints (factors that discourage their establishment and hinder the development of social enterprises).

Empirical studies in this area are very rare, because there no adequate databases on the number and achieved performances of social enterprises exist yet. An even more serious problem is the lack of a unified methodology for monitoring the success of social enterprises. Given the hybrid model of these enterprises, it is necessary to monitor the financial performances and the degree of success in achieving the social mission, which is not easy at all. There are dilemmas as to which social criterion is the most acceptable for monitoring the success of social enterprises, given that they can have very different social goals. The next dilemma is which indicator should be given priority in concluding (economic or social).

Despite numerous problems and dilemmas, certain empirical studies are present. For example, Yitshaki et al. (2008) examined the impact of external and internal factors on the long-term sustainability of social enterprises in Israel on a sample of 33 social enterprises. Using the descriptive statistical method, they concluded that the development of social enterprises was greatly influenced by the following factors: the ability to obtain financial resources, creating legitimacy, support from the local authorities, and creating entrepreneurial and personal networks of the founders with key stakeholders. A very serious empirical study on a sample of 26,000 respondents from 36 countries was conducted by Hoogendoorn, Thurik \& Van der Zwan (2019). They examined the influence of a large number of factors in the decision to establish a social enterprise, and made a comparison with the decision to establish a commercial enterprise. By applying the regression analysis method, they proved that the following factors have a statistically significant impact on the development of social entrepreneurship: availability of financial resources, characteristics of social entrepreneurs, and complexity of administrative procedures. Taking into account the results of numerous theoretical papers and empirical studies, we have grouped all factors into the following groups:

- Characteristics of the social entrepreneur,

- Characteristics of social business, and

- Characteristics of the macroeconomic environment in which the social business operates.

\section{Characteristics of the Social Entrepreneur}

The first group of factors is related to the demographic characteristics of the social entrepreneur, his/her entrepreneurial orientation, skills, and knowledge that he/she possesses etc. Previous studies show that age and gender have a certain impact on the decision to start a social business and perseverance in its development (Hoogendoorn et al., 2019). Global Entrepreneurship Monitor (GEM) shows that members of the younger generation are more willing to start their own business than the older 
generation (Bosma et al, 2015, p. 21). However, Parker's neoclassical life cycle theory has a completely different view. This theory predicts that the two dominant groups of social entrepreneurs are: idealistic entrepreneurs, those that create a business at a younger age, and wealthy individuals, who deal with social entrepreneurship at an older age, as evidenced by empirical study conducted by Hoogendoorn et al. (2019).

Regarding gender, most previous studies proved that women are more inclined to start entrepreneurial ventures with a social mission (Hoogendoorn et al., 2019). The impact of education has not been fully examined, so it is not possible to say with certainty whether level of education increases the likelihood of dealing with social entrepreneurship, and how it affects its success (Nga \& Shamuganathan, 2010).

The entrepreneurial orientation has a much greater impact than demographic characteristics on starting and developing a new business in the social sphere, especially the ability to create a vision, risk propensity, perseverance, commitment, and the like. First of all, the decision to start a social enterprise requires an extremely clear vision, great enthusiasm, and emphasized moral responsibility that encourages engagement in the social sphere (Zahra et al., 2009). The social entrepreneur must have a clear vision of what society would look like if the problem that he or she identified was solved (Best, 2018). This image inspires him/her, and encourages enthusiasm to find solutions in the direction of its realization. It also shows to the entrepreneur the direction of action, and clear steps to achieve it. In order for a social entrepreneur to succeed and remain persistent during the crisis, it is necessary to develop extremely high moral responsibility, empathy for other people's problems, etc. (Martin \& Osberg, 2015, p. 34).

The next important characteristic of an entrepreneur is risk propensity. It is important for all entrepreneurs, because it plays an important role in decision-making as for whether to deal with the entrepreneurship or not (Zahra et al., 2008; Shaw \& Carter, 2007; Tan et al., 2005; Peredo, 2006). However, this does not mean that all groups of entrepreneurs face the same types of risks. In social entrepreneurship, reputation and pervasiveness are important, and personal and family resources are rarely used as sources of funding (Shaw \& Carter, 2007). In this regard, social entrepreneurs face a lower degree of personal financial risk. Instead, they face a personal risk of a non-financial nature (loss of reputation in society). Empirical study conducted by Hoogendoorn et al. (2019) confirms that social entrepreneurs are more willing to face risks of a non-financial type, such as the risk of losing their reputation in society.

Appraisal of entrepreneurship knowledge, skills, and experience might have a direct influence on the intentions of all entrepreneurs. Entrepreneurial activity depends largely on how people perceive the feasibility of the new business. Entrepreneurial skills and knowledge make it easier for an individual to recognize market opportunities and start a new business. Entrepreneurial experience affects the efficiency of current and future decision-making (Genty et al., 2015). In addition to the knowledge, skills, and experience in the field of entrepreneurship, social entrepreneurs need certain knowledge that is not necessary for commercial entrepreneurs. Given that social entrepreneurs are very often financed by various funds, knowledge in the field of project management, ability to negotiate with local authorities, etc., is needed (Haugh, 2007; Sharir \& Lerner, 2006). Related to this is specific knowledge of accounting and financial management, such as: the calculation of grants and overheads; ad hoc or emergency projects. 


\section{Characteristics of the Social Enterprises}

The next group of factors is related to the characteristics of social enterprises. The need to create economic and social value makes the business of social enterprises much more complex than commercial enterprises, and their success can be greatly influenced by the ability to obtain and use financial and human resources. The management of human resources can also have an impact on the survival and development of social enterprises. Social enterprises mainly employ members of marginalized social groups. Finding these employees is generally not a problem, but their socialization and education can very often be a problem which limits the development of a social enterprise. Members of marginalized social groups are mostly people who have been unemployed or completely excluded from society for many years, so they face difficulties to adapt to the rules imposed by a social entrepreneur, and very often do not have an appropriate attitude towards the authorities, many of them finding it difficult to adopt new knowledge. All these problems can place a serious barrier to the development of business of social entrepreneurs (Austin et al., 2006; Haugh, 2007; Parker, 2009).

Very important elements that affect the success of the social business are the company characteristics, such as: location, size, activity, etc. Many social entrepreneurs locate their business in areas where the market is not sufficiently developed, which can create problems in generating income, because the low standard of living of the population does not promise growth in demand and an increase in the volume of work. In addition, the products and services of social enterprises are very often intended for vulnerable social groups, consumers who are often unable to pay a real economic price for them, so many of them give products to the most vulnerable groups for free or at a price determined by consumers. This can create problems in regular revenue generation and ensuring economic sustainability (DiDomenico et al., 2010; Mair \& Marti, 2006).

The size of social enterprises can affect costs because the advantage of economies of scale cannot be taken. The increase in costs is additionally influenced by the large share of manual labor (due to the tendency to employ as many members of marginalized social groups as possible, a lower degree of automation and dominance of manual labor, and many of these companies use traditional technology, seek to maintain the old crafts, which also imply manual work). Social enterprises very often cover specific market corners in order to be competitive. These can be: organic production, traditional crafts, food preparation, production of products to order or services on request, etc. (Ivanovic-Djukic \& Seldenbah, 2019). In countries where social enterprises are more developed, this problem is partially solved by grouping enterprises with the aim of exchanging information and innovation, and using economies of scale in certain sectors (Nicholls, 2009; Borzaga, et al, 2020, p. 19).

\section{Characteristics of the Macroeconomic Environment}

Macroeconomic environment includes several segments, such as: institutional framework (legislative framework, level of corruption, market demand, access to raw materials, etc.), financial support (availability and cost of capital and opportunities of finance) and social ambience (related to establishing relationships with key stakeholders, local authorities, establishing support for local and national authorities, etc.) (Dorado, 2006; Sharir \& Lerner, 2006; Ivanović-Đukić, et al. 2019).

The institutional framework can have a major impact on business of social enterprises and their achieved results (Zahra et al., 2008). Various financial incentives, tax incentives, incentives to employ marginalized social groups, can act as an incentive to establish social enterprises (Corner \& Ho, 2010). Also, the presence of support, understanding, and assistance from national and local authorities can 
have a great impact on the development and improvement of the business of social enterprises, which in turn creates great benefits for that same community (Mair \& Martí, 2006). For example, launching various projects to solve current social problems of the social community can stimulate the establishment of social enterprises (Haugh, 2007). Likewise, funding and providing institutional assistance and support to the social entrepreneurs' initiatives can lead to the improvement of social enterprise operations and their development (Hoogendoorn, et al., 2010).

In contrast, an unfavorable tax system and various discriminatory legal regulations can pose a serious burden to social enterprises (Mair \& Martí,, 2009). Likewise, complicated administrative procedures and a lack of legislation in the field of social economy can pose serious barriers to the establishment of social enterprises (Van der Zwan et al., 2010). However, the presence of corruption forces social entrepreneurs to invest and spend part of their resources on bribery, which reduces their limited resources and limits its development (Hoogendoorn et al., 2019). This can further increase the uncertainty and costs of doing business for social enterprises, and reduce their growth opportunities.

The ability to provide financial resources is a factor which has an extremely large impact on all entrepreneurs. Several studies have shown that social entrepreneurs face more difficulties in obtaining financial resources compared to commercial entrepreneurs (Sharir \& Lerner, 2006; Zahra et al., 2009). First of all, the return on investment in social enterprises is difficult to estimate (because profit is not the primary goal, as it is in commercial enterprises), which makes it difficult or impossible for social entrepreneurs to access the capital market (Weerawardena \& Mort, 2006). Thus, social entrepreneurs often use funds intended to create social value of the public sector, or from philanthropists and from commercial investments and lending from the private sector (Lyons \& Kickul, 2013). In addition, social enterprises can gain access to finance from various donor groups for projects that result in a certain social contribution (Best, 2018; Austin et al. 2006; Nicholls, 2009; Zahra et al., 2009). In recent years, social entrepreneurs have increasingly used crowdsourcing and crowdfunding, especially in the start-up phase. Crowdfunding financing is considered the fastest way to find interested investors, using available sites dedicated to this goal (Best, 2018). These sources of financing can have a major impact on the social enterprise operations. Meanwhile, access to these resources is largely conditioned by the business characteristics, the activities of social enterprises, the legal form, as well as the information of its founders and experience in project management.

Social capital (trust, networks of social entrepreneurs, their connections with government representatives, etc.) can play a very important role in the development of social enterprises (Vidal, 2005). However, lack of social capital can be a serious limitation to the development of social enterprises. Without trust in local authorities and business partners, social entrepreneurs will always be careful when investing additional capital and hiring new employees, which will reduce the use of their maximum effects for the social community (Hoogendoorn et al., 2019).

\section{METHODOLOGY}

\section{The Context of the Research and the Hypotheses Development}

The development of social entrepreneurship, as well as the establishment of social enterprises in the Republic of Serbia, began in 2000. However, there are no exact data on how many social enterprises exist, nor what their characteristics are. The only research on the number and nature of social enterprises was conducted within the study Mapping of Social Enterprises (2011), according to which there were 1,160 social enterprises. However, later studies have shown that many of the companies mapped 
as social enterprises (SEs) do not meet the criteria set for social enterprises. The real number of social enterprises that meet the conditions defined by the EU are much smaller (Vukmirović et al., 2014). According to the latest EU report, the estimated number of SEs in Serbia is 411, the number of SEs per million inhabitants is 59 (Borzaga, et al, 2020, p. 106).

Various barriers are the cause of the limited number of social enterprises in the Republic of Serbia. Previous studies show that obtaining financial resources is one of the most serious barriers of all entrepreneurs in Serbia (Culkin \& Simmons, 2019, p. 50; Rakic, 2018, p. 12). The challenges of social entrepreneurs are even higher compared to other entrepreneurs (Kusinkova \& Rosandić, 2017, pp. 24-28; Borzaga, et al, 2020, p. 141). Unlike most developed countries, where the registration of a social enterprise receives a grant from the state, in the Republic of Serbia there are still almost no incentives set aside for the establishment of social enterprises (Rosandić, 2018). Moreover, the Republic of Serbia is characterized by investors' lack of interest in investing in this type of business, primarily due to: insufficient attractiveness (high return on investment cannot be expected, and the state does not stimulate investment in this sector with tax relief or any other measures) and possible problems (wrong or late decisions) due to democratic decision-making (where decisions are not made on the basis of ownership). Even when social entrepreneurs provide a modest initial capital, they very often have problems with finding and equipping business space, procuring equipment, providing raw materials, etc. (Borzaga, et al, 2020, p. 145).

Non-governmental organizations (NGOs) have played significant role in overcoming this problem (Vukmirović et al., 2014). NGOs found various financial support programs for the development of social enterprises, and encouraged individuals with a strong moral responsibility to launch projects with a social mission. The largest number of new social enterprises in Serbia has evolved from these social projects (financed by various international and national funds) funds (Vukmirović et al., 2014; Ivanović-Djukic \& Seldenbah, 2019). In other words, financial incentives were a significant incentive for the establishment of social enterprises in Serbia. Our first hypothesis is:

H1: Favorable sources of financing (especially grants) are the factors that have the greatest positive impact on the establishment of social enterprises in the Republic of Serbia.

The results of recent studies conducted in Serbia have shown that, among new social enterprises, there are those that have entrepreneurial capacity and follow a clear social vision and, thus, achieve a significant social effect (Kusinikova \& Rosandić, 2017). One of the reasons are the characteristics of their founders. The founders of social enterprises in the Republic of Serbia are characterized by a high degree of self-initiative and commitment to solving various social problems, and a high degree of ethical responsibility. Among the founders of social enterprises, great enthusiasm is especially visible when forming a company: the best intention exists to do something good for a specific vulnerable group and, eventually, for themselves (Borzaga, et al, 2020, p. 141). This enthusiasm often knows how to overcome obstacles that seem insurmountable and to help those who would not find help on the other side. Due to their enthusiasm and persistence, social enterprises in the Republic of Serbia survive, despite all the problems. Accordingly, our second hypothesis is:

$\mathrm{H} 2$ : The enthusiasm of the social entrepreneur and their commitment to solving their chosen social problem are factors that have the greatest positive impact on the survival and development of social enterprises in the Republic of Serbia. 
A very serious limitation on the establishment and development of social enterprises in the Republic of Serbia is the unfavorable institutional framework due to which problems arise when entering the market. The Law on Social Entrepreneurship has not yet been adopted in the Republic of Serbia. Its adoption has been waited for many years, as well as the establishment of a budget fund to encourage the development of social enterprises. In order to register and legally run social enterprises, several other laws must be consulted, which can have a disincentive effect on potential entrepreneurs when making a decision to start a business (Ivanović-Đukić \& Seldenbah, 2018).

Access to the market can be a much more serious problem. If a social enterprise is established in industries related to social protection, or in service activities, barriers to market entry are generally not large, as capital investment is usually modest and often does not require a highly skilled workforce. Therefore, social enterprises can attract consumers relatively easily, and access the market. However, if a social enterprise intends to operate in other industries, market access is extremely difficult. For example, it is necessary to provide significant capital for the establishment of a social enterprise in the field of industrial production. Since grants and favorable funds are limited, the social entrepreneur must invest his or her own capital, or give up on their job. The offer of products in branches where there is a large number of large companies, which produce machines, prevents access to social enterprises, because labor costs have a large share in their work (many jobs are done manually, hiring as many members of marginalized social groups as possible). Since there are no financial incentives for social enterprises in the Republic of Serbia, and consumers' awareness of their role in society is low (so they do not choose their products), their competitive position in these branches is very unfavorable. Many studies show that trust of the population (potential consumers) in the services of social enterprises in the initial period is very low, which also decreases the likelihood of their success in the initial period (Vukmirović et al., 2014; Kusinkova \& Rosandić, 2017).

Overall, there are a number of challenges for social entrepreneurs in Serbia's macroeconomic environment. For these reasons, they perceive it as unfavorable. We assume that such an unfavorable environment has a disincentive effect on the establishment and development of social enterprises in Serbia. Therefore, our next hypothesis is:

$\mathrm{H} 3$ : The macroeconomic environment is factor which has the greatest negative impact on the establishment of social enterprises in the Republic of Serbia.

The next factor that has a great impact on the development of social enterprises is the knowledge and experience of their founders in managing a business. The founders of most social enterprises in the Republic of Serbia are people from non-economic educational profiles (journalists, sociologists, artists, etc.), who work on achieving social missions, but do not have enough experience in marketing, sales, financial management, business performance monitoring, business negotiations, etc. (Ivanovic-Djukic \& Seldenbah, 2018). Due to the lack of knowledge and experience in the field of management, the following problems often occur: poor organization and division of labor (one person works everything, which reduces productivity and increases costs).

Lack of knowledge in the field of marketing leads to the fact that they do not have clearly defined products, do not perform market analysis, and do not know to whom they can sell their products, do not examine the behavior of competitors and set the prices of their products very high, do not know the customer communication procedure and promotional activities (they don't have developed promotional materials, they don't have a website or a Facebook page), so they don't have a brand built. All this, along with the lack of sales skills, limits the income of social workers, so they are often 
financially dependent on donors or the state. A particular problem that emerges is that most social enterprises do not have the resources to hire partners (designers, web designers, marketing agencies, etc.) who could help overcome these problems, which significantly slows down the development of social enterprises. Our last hypothesis is:

H4: The lack of knowledge and experience in management and marketing are factors that significantly limit the development of social enterprises in the Republic of Serbia.

The Sampling Method and Sample Characteristics

To analyze the success factors of social enterprises in the Republic of Serbia, we conducted a primary survey. Research was conducted in the second half of 2019, by surveying the founders of social enterprises in the Republic of Serbia. The research covered 27 social enterprises.

The questionnaire included two parts. The first part of the questionnaire consisted of questions related to general information about the founder/s and the characteristics of social enterprises. The second part of the questionnaire was related to the attitudes of the founders of social enterprises about the factors that act as an incentive and restrictive on the establishment of social enterprises in the Republic of Serbia.

The following characteristics of the founders of social enterprises were examined: age, education, gender, previous entrepreneurial experience, and previous managerial experience. In terms of age and education, the structure is as follows: the largest share is founders under the age of 45 , and people with a higher level of education. The age and educational structure are shown in Table 1.

Table 1. The Structure of a Sample in \%

\begin{tabular}{lcccc}
\hline \multicolumn{1}{c}{ Age } & $\begin{array}{c}\text { Primary } \\
\text { education }\end{array}$ & $\begin{array}{c}\text { Secondary } \\
\text { education }\end{array}$ & $\begin{array}{c}\text { Post-secondary } \\
\text { education }\end{array}$ & Total \\
\hline $\begin{array}{l}25 \text { and } \\
\text { under }\end{array}$ & 1.0 & 10.7 & 13.0 & 24.7 \\
\hline $26-30$ & 1.1 & 18.0 & 9.7 & 28.8 \\
\hline $31-45$ & 1.0 & 16.6 & 13.0 & 30.6 \\
\hline $46-60$ & 0.5 & 7.3 & 6.6 & 14.4 \\
\hline over 60 & 0.1 & 0.6 & 0.8 & 1.5 \\
\hline Total & 3.7 & 53.2 & 43.1 & 100.0 \\
\hline
\end{tabular}

Source: Author's own calculation

Regarding the gender structure, $78 \%$ of companies are founded by women, while men are founders of $22 \%$ of social enterprises. In the total sample, only $15 \%$ of founders had previous managerial experience, and $12 \%$ of respondents had previous entrepreneurial experience.

The next segment consisted of the characteristics of social enterprises: age, size, legal form. Regarding the age of enterprises, the structure is as follows: enterprises under 1 year of age accounted for $16 \%$ of the sample, enterprises between 1 and 3 years of age accounted for 36\%, enterprises between 3 and 5 years of age accounted for $28 \%$ and enterprises operating for more than 5 years accounted for $20 \%$ of the sample. In terms of size, $80 \%$ of enterprises belong to the group of micro-enterprises, while the rest (20\%) belongs to small enterprises. $20 \%$ were social enterprises registered as citizens' associations companies (craft cooperatives), public-civil partnerships were $4 \%$, and associations for professional rehabilitation of the disabled person were $12 \%$. 
Regarding the sources of financing, 50\% of the funds for the establishment of the largest number of social enterprises in the Republic of Serbia were provided from international funds, the companies for which establishment were provided funds by account slightly smaller share (30\%), and $20 \%$ of social enterprises were financed by the personal savings of their founders.

The second part of the questionnaire was related to the attitudes of the social enterprises founders concerning the factors that influence the establishment and development of social enterprises in the Republic of Serbia, according to their perception. A five-point Likert scale was used to evaluate the answers, starting from 1 - I do not agree at all, up to 5 - I completely agree.

\section{Model and Variables}

To check the validity of the hypotheses, a regression analysis was applied. Two regression models were formed. The first examines the impact of certain groups of factors on the establishment of a social enterprise. The second examines the impact of factors on the social enterprise development.

The dependent variable was successfully measured on the basis of a long-term sustainability rate, following an example of research conducted by Yitshaki (2008). The long-term sustainability rate was measured based on the average income growth rate and the average growth rate of success in achieving social goals. The average success rate in achieving social goals is measured by the average growth rate of the number of employees, members of marginalized social groups or the average growth rate of members of vulnerable social groups who were provided assistance.

The independent variables in the first model were factors that had the greatest impact on the establishment of social enterprises according to the perception of entrepreneurs. Meanwhile, independent variables in the second model were factors influencing development of social enterprises (according to the perception of social entrepreneurs).

\section{RESULTS AND DISCUSSION}

The average values of the attitudes of the founders of social enterprises concerning the influence of certain factors on the operations of social enterprises are given in Table 2.

As can be seen, the majority of the founders of social enterprises believe that available financial resources, the possibility of obtaining other resources, and the recognized market opportunities (unmet need of a vulnerable group or a social problem that must be solved) stimulate the establishment of social enterprises. Meanwhile, the majority of the respondents disagree with the claim that legal regulations, local government support, and market access had a stimulating effect on starting a social business.

Regarding to the factors influencing the development of social enterprises, the opinion of most of the surveyed founders is that very important factors that contribute to the development of their enterprises are their enthusiasm, commitment, and persistence in solving social problems, and knowledge in project management that allows them to provide additional funding. Moreover, the majority of respondents do not agree with the statement that their knowledge in the field of management and marketing contributes to the development of their business. The attitude towards knowledge in the field of human resource management is approximately neutral. 
Table 2. Descriptive Statistics

\begin{tabular}{|c|c|c|}
\hline Variable & Mean & $\begin{array}{l}\text { Standard } \\
\text { Deviation }\end{array}$ \\
\hline Sustainability rate & 1.83 & 1.03 \\
\hline $\begin{array}{l}\text { Available financial resources had an incentive for the establishment } \\
\text { of the SP }\end{array}$ & 4.89 & 0.53 \\
\hline $\begin{array}{l}\text { The possibility of obtaining resources had an incentive to establish } \\
\text { the SP }\end{array}$ & 4.78 & .950 \\
\hline Legal regulations and state support had an incentive to establish the SP & 1.25 & 0.79 \\
\hline Support of local authorities had an incentive to establish the SP & 1.32 & 1.23 \\
\hline Easy market access had an incentive to establish the SP & 2.28 & 1.04 \\
\hline $\begin{array}{l}\text { A recognized market need had an incentive for the establishment of } \\
\text { the SP }\end{array}$ & 3.73 & 1.42 \\
\hline My enthusiasm has a positive effect on the development of the SP & 4.12 & 0.99 \\
\hline $\begin{array}{l}\text { My commitment (persistence) to solving social problems has a positive } \\
\text { effect on the SP development }\end{array}$ & 4.68 & 1.14 \\
\hline $\begin{array}{l}\text { My knowledge and experience in management affect the SP } \\
\text { development }\end{array}$ & 2.76 & 1.17 \\
\hline My knowledge and experience in marketing affect the SP development & 2.98 & 1.45 \\
\hline My knowledge of project management affect the SP development & 3.93 & 1.04 \\
\hline $\begin{array}{l}\text { My knowledges related to human management affect the SP } \\
\text { development }\end{array}$ & 3.11 & 0.75 \\
\hline Valid N & 27 & \\
\hline
\end{tabular}

Source: Author's own calculation

In order to check whether the influence of these factors was statistically significant in the long-term sustainability of social enterprises, a regression analysis was performed. The results are shown in Table 3:

Table 3 Regression Analysis

\begin{tabular}{lcc}
\hline \multicolumn{1}{c}{ Variable } & Model 1 & Model 2 \\
\hline Constant & 2.099 & $3.838^{*}$ \\
\hline $\begin{array}{l}\text { Available financial resources had an incentive for the establishment } \\
\text { of the SP }\end{array}$ & $0.98^{* *}$ & 0.65 \\
\hline $\begin{array}{l}\text { The possibility of obtaining resources had an incentive to establish } \\
\text { the SP }\end{array}$ & $-0.67^{*}$ \\
\hline $\begin{array}{l}\text { Legal regulations and state support had an incentive to establish the SP } \\
\text { Support of local authorities had an incentive to establish the SP }\end{array}$ & 0.02 \\
\hline $\begin{array}{l}\text { Easy market access had an incentive to establish the SP } \\
\begin{array}{l}\text { A recognized market need had an incentive for the establishment of } \\
\text { the SP }\end{array}\end{array}$ & $-0.17^{* *}$ \\
\hline
\end{tabular}




\begin{tabular}{lcc}
\hline \multicolumn{1}{c}{ Variable } & Model 1 & Model 2 \\
\hline My enthusiasm has a positive effect on the development of the SP & & $0.49^{* *}$ \\
\hline $\begin{array}{l}\text { My commitment (persistence) to solving social problems has a } \\
\text { positive effect on the SP development }\end{array}$ & $0.84^{*}$ \\
\hline $\begin{array}{l}\text { My knowledge and experience in management affect the SP develop- } \\
\text { ment }\end{array}$ & $-0.38^{*}$ \\
\hline $\begin{array}{l}\text { My knowledge and experience in marketing affect the SP development } \\
\text { My knowledge of project management affect the SP development }\end{array}$ & $-0.64^{* *}$ \\
\hline My knowledges related to human management affect the SP development & $0.43^{*}$ \\
\hline $\mathrm{R}$ & 0.3216 & 0.05 \\
\hline $\mathrm{R}^{2}$ & 0.2913 & 0.3458 \\
\hline
\end{tabular}

Dependent variable: Long-term survivability rat; Significance:** at $5 \%{ }^{*}$ at $10 \%$.

Source: Author's own calculation

The available financial resources (grants, subsidies, etc.) have the greatest positive impact on the establishment of social enterprises. The impact of this factor was positive and statistically significant at a significance level of $10 \%$. In this way, the first hypothesis was proved. The possibility of obtaining other resources (business space, equipment, materials...), the recognized need from the market, and the support of local authorities are also factors which have a positive impact on the establishment of social enterprises, but the impact of these factors was not statistically significant. However, elements of the institutional environment, legal regulations, state support, and market access negatively impact the establishment of social business. The impact of these factors is statistically significant, which proves the second hypothesis.

The second model shows that the greatest positive impact on the development of social enterprises is the enthusiasm and the commitment of founders to solve social problems, to a somewhat smaller degree, but knowledge in the field of project management also has a positive impact. The impact of all of these factors is statistically significant, which proves the third hypothesis. A limitation of the social enterprises' development is the lack of knowledge and experience in the field of marketing and management. These factors negatively affect the social enterprises' long-term sustainability, and their impact is statistically significant. This proves the last hypothesis. The knowledge of the founders related to human resource management has a positive, but statistically insignificant, impact on the development of social enterprises.

\section{Discussion and Recommendations for the Economic Policymakers}

The results of the research have shown that a very significant incentive for the establishment of social enterprises is the availability of resources, primarily financial. This is in line with all previous studies conducted globally, (Sharir \& Lerner, 2006; Zahra et al., 2009) as well as in the Republic of Serbia (Rosandić, 2018; Rakic, 2018; Culkin \& Simmons, 2019). This can be explained by the fact that favorable financial resources are very limited in the Republic of Serbia, while the capital market is almost underdeveloped, banks have very unfavorable lending conditions for beginners (and commercial entrepreneurs); and social enterprises are forced to find their own sources of financing. This problem can be solved by offering much more incentive funds for social entrepreneurs from state funds or local community funds. 
Furthermore, it can be useful to organize trainings for the founders of social enterprises in the field of project management, and provide the information on favorable sources of financing, in order to use funds from international funds intended for the development of social entrepreneurship.

The next group of factors identified by our research, with significant but negative impact on the development of social entrepreneurship, is legal regulations and the institutional framework. This is expected, given that the Republic of Serbia has not yet adopted the Law on Social Entrepreneurship, and there are no appropriate bodies in public administration responsible for development, coordination and monitoring in the field of social entrepreneurship, which creates problems for the development of this sector. This is in line with previous studies (Vukmirović et al., 2014; Kusinikova, \& Rosandić, 2017; Borzaga, et al., 2020). It is necessary to create laws and institutions for regulating social-entrepreneurial activities, and to facilitate the establishment and operation of social enterprises.

A legal framework is necessary in order to strictly define which activities are included in social entrepreneurship, and what their rights and responsibilities are. Moreover, it is necessary to include all institutions that have legal, financial and political power for the faster development of social entrepreneurship, and an increase in the number of social enterprises. Their task is to enable the creation of an institutional framework that encourages the establishment and development of social enterprises, by providing various financial incentives and tax relief. It is also necessary to consider opportunities for reducing taxes, contributions, and fees in order to provide greater incentives to social entrepreneurs.

It is also necessary to analyze the benefits of social entrepreneurship for socioeconomic development, and to better and more clearly develop the legal framework related to social entrepreneurship. In order to prove the importance of social entrepreneurship for the economy and employment, it is necessary to develop mechanisms for the documenting and statistical monitoring of social entrepreneurship. There is a need to encourage the development of social and business support institutions, such as social business incubators, development agencies, social business centers, business parks, etc.

Market access had a slightly less negative impact on the development of social enterprises, but statistically significant nonetheless. The main reason is primarily high costs, due to the large share of labor costs (most jobs are done by hand, because one of the goals of social enterprises is to employ as many members of marginalized social groups as possible, and very often to preserve old crafts and traditions). Due to high costs, the prices of their products are relatively high. Given that these companies often offer unique products and that these products are made by people from marginalized social groups, it is desirable to provide assistance from local authorities at the national level as well in the field of promotion of their products, subsidizing costs (especially labor costs of marginalized social groups).

In addition, the activities of policymakers should be routed towards raising public awareness of the role of social enterprises, which will in turn affect the growth of demand for their products. To raise awareness of the importance and role of social enterprises, it is important to transfer best practices and experiences from developed to less developed countries and from developed to less developed parts of the country. In addition to create an information system on the general concept of social entrepreneurship, it is desirable to promote products and services offered by existing social enterprises.

Among the characteristics of entrepreneurs, the factors that have a significant but negative impact on the development of social enterprises are the knowledge of social entrepreneurs in the field of management and marketing, which is similar to the previous research (Ivanović-Đukić, Seldenbach, 2019). It is necessary to organize a much larger number of trainings and workshops in the field of digital marketing, business planning, work organization, and other areas of management. It is also desirable to organize educational programs in the field of social entrepreneurship within the formal education program. 
There are currently very few such programs in the Republic of Serbia. Education in this area is organized mainly through informal educational events, such as conferences, symposiums, and workshops. In order to change the situation and improve the business of social enterprises, it is necessary to offer many more educational programs through a formal and informal education system.

The factors that have a significant and positive impact, which initiate (encourage) the establishment and development of social enterprises, are enthusiasm and emphasizing the moral responsibility of individuals, who become social entrepreneurs to help a vulnerable social group or help solve specific social problems. The importance of the personal characteristics of social entrepreneurs has been explained in many previous papers (Martin \& Osberg, 2015, p. 34 Best, 2018). In addition to various forms of help and support for social entrepreneurs, promotion and rewarding are needed. It is possible to introduce various forms of awards for the most successful social entrepreneur in a particular year. The award programs would be accompanied by certain promotional activities. In that way, enthusiasm and even greater engagement of these socially responsible people would be encouraged. At the same time, social entrepreneurship in the Republic of Serbia would be promoted and awareness of the population about the role and importance of social entrepreneurship would be raised.

\section{CONCLUSION}

This paper analyzes the factors that influence the establishment and development of social enterprises in the Republic of Serbia. Based on literature reviews and previous empirical studies, all factors are classified into the following groups: characteristics of the entrepreneur (demographic characteristics of the entrepreneur, his entrepreneurial orientation, possessed skills and knowledge); characteristics of the social enterprise (size, activity, legal form, management); and characteristics of the macroeconomic environment in which the business takes place (legislative framework, corruption, market demand, access to raw materials, difficulties in exports, delays in collection of claims, availability and price of capital, financial opportunities, the possibility of establishing relationships with key stakeholders, local authorities, establishing support from local and national authorities, etc.).

The primary research was conducted on the sample of 27 SE in order to identify the factors that have the greatest impact on the establishment of social enterprises in the Republic of Serbia. By applying the methods of regression analysis, it was found that favorable financial resources (especially grants) are key stimulants for the establishment of social enterprises (the first hypothesis of the paper is proven). Results show that enthusiasm of managers of social enterprises has the greatest impact on their development (the second hypothesis of the paper is proven). It was found also that legal regulations and the macroeconomic environment, as well as difficulties in accessing the market, are serious restrictions to the establishment of social enterprises (the third hypothesis of the paper is proven), while lack of knowledge in the field of marketing and management limit the development of social enterprises in the Republic of Serbia (the last hypothesis of the paper is proven).

Measures have been proposed to economic policymakers in the direction of mitigating the negative effects of disincentive factors and strengthening the effects of factors that positively affect the development of social entrepreneurship. 


\section{Limitations to the Study}

The study we conducted has several limitations. Firstly, the limitation of the study refers to the measurement of the development (success) of SE indicated by a long-term sustainability rate, following an example of research conducted by Yitshaki (2008). Secondly, the importance of different factors influencing the establishment and development of SE was measured on the basis of the perception of the surveyed entrepreneurs (subjective criteria). Some of the reasons for using unreliable and subjective measures of SE performance and the factors influencing them are a lack of accepted methodology and generally accepted indicators for monitoring the performance of social enterprises, as well as a very limited number of empirical research in this area. Our future research will be focused on the development of a universally accepted methodology, and the development of objective criteria for monitoring the success of social enterprises.

The next limitation of our paper is the sample size of 27 SEs. Such a sample is small compared to the similar research papers conducted worldwide. Consequently, the results we obtained may not be comparable enough with the results of the studies that have already been conducted in this area. However, if we take into account the fact that there are only 411 SEs in Serbia, (it is 6.5\%) our sample is representative $(6.5 \%)$.

\section{REFERENCES}

Austin, J., Stevenson, H. \& Wei-Skillern, J. (2006). Social and commercial entrepreneurship: Same, different, or both? Entrepreneurship Theory and Practice, 30(1), 1-22. DOI: 10.1111\%2Fj.1540-6520.2006.00107.x.

Bacq, S. \& Janssen, F. (2011). The multiple faces of social entrepreneurship: A review of definitional issues based on geographical and thematic criteria. Entrepreneurship and Regional Development, 23(5), 373-403. DOI: 10.1080/08985626.2011.577242.

Best, S. (2018). Social enterprises: challenges, constraints and operating conditions regarding moderation of social injustice. The Business and Management Review, 9(3), 221-228.

Borzaga, C., Galera,G., Franchini B., Chiomento S., Nogales, R. \& Carini, C. (2020). Social enterprises and their ecosystems in Europe. Comparative synthesis report. Luxembourg: Publications Office of the European Union. Retrieved April 30, 2020, from European Commission http://ec.europa.eu/social/publications.

Bosma, N., Schott, T., Teresjen, S. \& Kew, P. (2015). GEM Global Entrepreneurship Monitor: Social entrepreneurship. Retrieved March 30, 2020, from https://www.gemconsortium.org/report/gem-2015-report-onsocial-entrepreneurship.

Corner, D.P. \& Ho, M. (2010). How opportunities develop in social entrepreneurship. Entrepreneurship Theory and Practice, 34(4), 635-659. DOI: 10.1111/j.1540-6520.2010.00382.x.

Culkin, N. \& Simmons, R. (2019). Study of the challenges that hinder MSMe development in the Republic of Serbia. Country Report for the British Council and Swedish Institute. Belgrade: British Council. Retrieved March 30, 2020, from https://www.britishcouncil.rs/sites/default/files/study_of_the_challenges_that_hinder_msme_development_in_serbia_e-book_eng.pdf.

Defourny, J. \& Nyssens, M. (2006). Defining social enterprise. In: Nyssens, M. (Ed.), Social enterprises - at the crossroads of market, public policies and civil society (pp. 3-26). London and New York: Routledge.

DiDomenico, M., Haugh, H. \& Tracey, P. (2010). Social bricolage: Theorizing social value creation in social enterprises. Entrepreneurship Theory and Practice, 34(5), 681-703. DOI: 10.1111\%2Fj.1540-6520.2010.00370.x.

Dorado, S. (2006). Social entrepreneurial ventures: Different values so different process of creation, no? Journal of Developmental Entrepreneurship, 11(4), 319-343. DOI: 10.1142/S1084946706000453.

Feiler, J. \& Nayowith, B.G. (2017). The nonprofit risk book: finding and managing risk in nonprofits and NGOs. Boston/Berlin: Walter De-G Press. 
Fritsch, M., Brixy, U. \& Falck, O. (2006). The effect of industry, region, and time on new business survival - A multi-dimensional analysis. Rev Ind Organ, 28, 285-306. DOI: 10.1007/s11151-006-0018-4.

Genty, K. Idris, K., Wahat, N.W. \& Kadir, S. (2015). Demographic factors and entrepreneurial success: A conceptual review. International Journal of Management Sciences, 6(8), 366-374. Retrieved April 30, 2020, from IDEAS database: https://ideas.repec.org/a/rss/jnljms/v6i8p1.html.

Haugh, H. (2007). Community-led social venture creation. Entrepreneurship Theory and Practice, 31(2), 161-182. DOI: $10.1111 \% 2 \mathrm{Fj} .1540-6520.2007 .00168 . \mathrm{x}$

Hjorth, D. (2013). Public entrepreneurship: Desiring social change, creating sociality. Entrepreneurship and Regional Development, 25(1-2), 34-51. DOI: 10.1080/08985626.2012.746883.

Hoogendoorn, B., Pennings, E. \& Thurik, A.R. (2010). What do we know about social entrepreneurship; an analysis of empirical research. International Review of Entrepreneurship, 8(2), 71-112.

Hoogendoorn, B., van der Zwan, P.W. \& Thurik, A.R. (2017). Sustainable entrepreneurship: The role of perceived barriers and risk. Journal of business ethics, 157(2), 1133-1154. DOI: 10.1007/s10551-017-3646-8.

Ivanovic-Đukić, M. \& Seldenbah, M. (2019). Barijere rasta socijalnih preduzeća u Srbiji i Sloveniji. In: Ž. Gligorijević (Ed.), Regionalni razvoj i demografski tokovi zemalja Jugoistocne Evrope (pp. 469-480. Niš: Ekonomski fakultet Nis.

Ivanović-Đukić, M., Stevanović, T. \& Rađenović, T. (2019). Does digitalization affect the contribution of entrepreneurship to economic growth? Proceedings of Rijeka Faculty of Economics: Journal of Economics and Business, 36(2), 653-679. DOI: 10.18045/zbefri.2018.2.777.

Kusinikova, N., Rosandić, A.(2017). Social economy in eastern neighbourhood and in the Western Balkans, Country report - Serbia. AETS.

Lyons, S.T. \& Kickul, R.J. (2013). The social enterprise financing landscape: the lay of the land and new research on the horizon. Entrepreneurship Research Journal, 3(2), 147-159. DOI: 10.1515/erj-2013-0045.

Mair, J. \& Martí, I. (2009). Entrepreneurship in and around institutional voids: A case study from Bangladesh. Journal of Business Venturing, 24(5), 419-435. DOI: 10.1016/j.jbusvent.2008.04.006.

Mair, J. \& Mart1', I. (2006). Social entrepreneurship research: A source of explanation, prediction, and delight. Journal of World Business, 41(1), 36-44. DOI: 10.1016/j.jwb.2005.09.002.

Martin, R.L. \& Osberg, S.R. (2015). Getting beyond better: how social entrepreneurship works. Boston, Massachusetts: Harvard Business Review Press.

Moizer, J. \& Tracey, P. (2010). Strategy making in social enterprise: the role of resource allocation and its effects on organizational sustainability. Systems Research and Behavioral Science, 27(3), 252-266. DOI: $10.1002 /$ sres.1006.

Nga, J.K. \& Shamuganathan, G. (2010). The influence of personality traits and demographic factors on social entrepreneurship start up intentions. Journal of Business Ethics, 95(2), 259-282. DOI: $10.1007 / \mathrm{s} 10551-009-0358-8$.

Nicholls, A. (2009). We do good things, don't we? Blended value accounting in social entrepreneurship. Accounting, Organizations and Society, 34(6-7), 755-769. DOI: 10.1016/j.aos.2009.04.008.

OECD/European Commission (2013). policy brief on social entrepreneurship entrepreneurial activities in Europe. Luxembourg: Publications Office of the European Union. Retrieved April 10,2020, from https://www.oecd. org/cfe/leed/Social\%20entrepreneurship\%20policy\%20brief\%20EN_FINAL.pd

Parker, S. C. (2009). The Economics of entrepreneurship. Cambridge, UK: Cambridge University Press.

Peredo, A.M. \& McLean, M. (2006). Social entrepreneurship: A critical review of the concept. Journal of World Business, 41(1), 56-65. DOI: https://doi.org/10.1016/j.jwb.2005.10.007.

Rakić, I. (2018) EY Preduzetnički barametar. Beograd: Republika Srbija, Ministarstvo privrede. . Retrieved April 30, 2020, from https://www.ey.com/Publication/vwLUAssets/EY_Preduzetni\%C4\%8Dki_ barometar_2018./\$File/EY\%20Preduzetni\%C4\%8Dki\%20barometar\%202018.pdf.

Rosandić, A. (2018) Social economy in eastern neighbourhood and in the Western Balkans. AETS. 
Sharir, M. \& Lerner, M. (2006). Gauging the success of social ventures initiated by individual social entrepreneurs. Journal of World Business, 41(1), 6-20. DOI: 10.1016/j.jwb.2005.09.004.

Shaw, E. \& Carter, S. (2007). Social entrepreneurship: Theoretical antecedents and empirical analysis of entrepreneurial processes and outcomes. Journal of Small Business and Enterprise Development, 14(3), 418-434. DOI: $10.1108 / 14626000710773529$.

Stefanović, S., Ivanović-Djukić, M. \& Janković-Milić, V. (2013). The analysis of key challenges and constraints to the stability and growth of an entrepreneurial sector in Serbia. Journal of Balkan and Near Eastern Studies, 15(3), 364-365. DOI: $10.1080 / 19448953.2013 .789330$

Tan, W.L., Williams, J. \& Tan, T.M. (2005). Defining the 'social' in 'social entrepreneurship': Altruism and entrepreneurship. The International Entrepreneurship and Management Journal. 1(3), 353-365. DOI: $10.1007 / \mathrm{s} 11365-005-2600-x$.

Van der Zwan, P.V.D., Thurik, A R. \& Grilo, I. (2010). The entrepreneurial ladder and its determinants. Applied Economics, 42(17), 2183-2191. DOI: 10.1080/00036840701765437.

Vidal, I. (2005). Social enterprise and social inclusion: Social enterprises in the sphere of work integration. International Journal of Public Administration, 28(9), 807-825. DOI: 10.1081/PAD-200067347.

Vukmirović, D. et al. (2014). Economic impact of social enterprises in the Republic of Serbia. Begrade: National Statistical Office. Retrieved April 30, 2020, from http://socijalnoukljucivanje.gov.rs/wp-content/ uploads/2014/06/economic_impact_of_social_enterprises_in_the_republic_of_serbia_RZS.pdf.

Weerawardena, J. \& Sullivan Mort, G. (2006). Investigating social entrepreneurship: A multidimensional model. Journal of World Business, 41(1), 21-35. DOI: 10.1016/j.jwb.2005.09.001

Yitshaki, M., Lerner, M. \& Sharir, M. (2008). What are social ventures? Toward a theoretical framework and empirical examination of successful social ventures. In G.E. Shockley, P.M. Frank \& R.R. Stough (Eds.), Non-market Entrepreneurship: Interdisciplinary Approaches (pp. 217-241). Cheltenham, UK: Edgar Elgar.

Zahra, S.A., Gedajlovic, E., Neubaum, D.O. \& Shulman, J. M. (2009). A typology of social entrepreneurs: Motives, search processes and ethical challenges. Journal of Business Venturing, 24(5), 519-532.

DOI: 10.1016/j.jbusvent.2008.04.007.

Zahra, S.A., Rawhouser, H.N., Bhawe, N., Neubaum, D.O. \& Hayton, J.C. (2008). Globalization of social entrepreneurship opportunities. Strategic entrepreneurship Journal, 2(2), 117-131. DOI: 10.1002/sej.43. 


\section{ANALIZA FAKTORA KOJI UTIČU NA RAZVOJ SOCIJALNIH PREDUZEĆA U REPUBLICI SRBIJI}

\section{Rezime:}

U radu je ispitivan uticaj različitih faktora na osnivanje i razvoj socijalnih preduzeća. Cilj rada je bio da se identifikuju ključni podsticaji i ograničenja razvoja socijalnih preduzeća u Srbiji i predlože mere čija primena može povećati njihovu dugoročnu održivost. Rad je zasnovan na empirijskom istraživanju u kome su korišćeni podaci dobijeni anketiranjem 27 osnivača socijalnih preduzeća u Srbiji. Primenom metoda regresione analize je pokazano da su najveći stimulansi za osnivanje socijalnih preduzeća povoljni izvori finansiranja (naročito bespovratna sredstva), dok najveći uticaj na razvoj socijalnih preduzeća ima entuzijazam i posvećenost njihovih menadžera. Rezultati su takođe pokazali, da pravni propisi i makroekonomski ambijent destimulišu osnivanje socijalnih preduzeća, dok nedostatak znanja u oblasti marketinga i menadžmenta ograničavaju njihov razvoj.

\section{Ključne reči:}

Socijalna preduzeća, podsticaji, ograničenja, dugoročna održivost. 